Received: 15 February 2017

Accepted: 16 May 2017

Published online: 23 June 2017

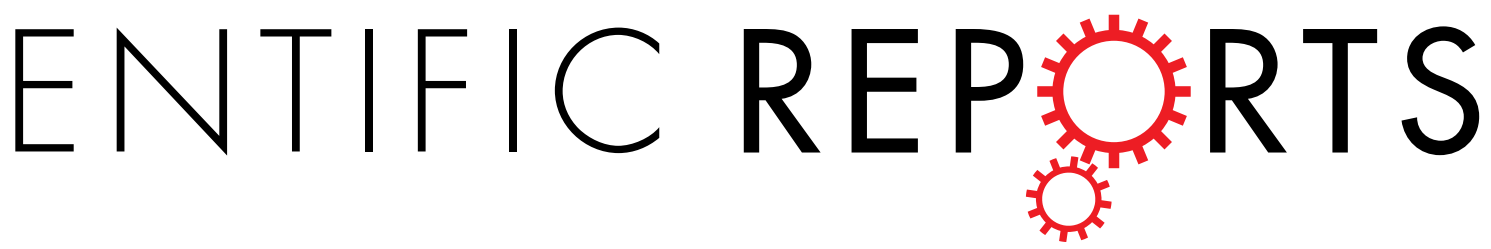

\title{
The relation between residual stress, interfacial structure and the joint property in the $\mathrm{SiO}_{2 f} / \mathrm{SiO}_{2}-\mathrm{Nb}$ joints
}

\author{
Qiang Ma, Zhuo Ran Li, Lai Shan Yang, Jing Huang Lin, Jin Ba, Ze Yu Wang, Jun Lei Qi \& \\ JiCai Feng
}

In order to achieve a high-quality joint between $\mathrm{SiO}_{2 f} / \mathrm{SiO}_{2}$ and metals, it is necessary to address the poor wettability of $\mathrm{SiO}_{2 f} / \mathrm{SiO}_{2}$ and the high residual stress in $\mathrm{SiO}_{2 f} / \mathrm{SiO}_{2}-\mathrm{Nb}$ joint. Here, we simultaneously realize good wettability and low residual stress in $\mathrm{SiO}_{2 f} / \mathrm{SiO}_{2}-\mathrm{Nb}$ joint by combined method of $\mathrm{HF}$ etching treatment and Finite Element Analysis (FEA). After etching treatment, the wettability of $\mathrm{E}-\mathrm{SiO}_{2 \mathrm{f}} / \mathrm{SiO}_{2}$ was improved, and the residual stress in the joint was decreased. In order to better control the quality of joints, efforts were made to understand the relationship between surface structure of $\mathrm{E}-\mathrm{SiO}_{2 \mathrm{f}} / \mathrm{SiO}_{2}$ and residual stress in joint using $\mathrm{FEA}$. Based on the direction of FEA results, a relationship between residual stress, surface structure and joint property in the brazed joints were investigated by experiments. As well the FEA and the brazing test results both realized the high-quality joint of $\mathrm{E}-\mathrm{SiO}_{2 \mathrm{f}} / \mathrm{SiO}_{2}-\mathrm{Nb}$ and the shear strength of the joint reached $61.9 \mathrm{MPa}$.

$\mathrm{SiO}_{2 \mathrm{f}} / \mathrm{SiO}_{2}$, one of the most significant functional and structural quartz fiber reinforced silica ceramic matrix composites, has been attracted great attention in aerospace industry applications, due to its high thermal shock resistance, excellent ablation resistance as well as low thermal conductivity ${ }^{1-6}$. However, like most advanced ceramic matrix composites, it is difficult for $\mathrm{SiO}_{2 f} / \mathrm{SiO}_{2}$ to fabricate large-sized or complex-shaped components owing to its intrinsic brittleness and low fracture $\operatorname{strain}^{7-12}$. Therefore, it is indispensable to develop a reliable technique to joint $\mathrm{SiO}_{2 \mathrm{f}} / \mathrm{SiO}_{2}$ with metals to extend the application of the composite.

Due to the intrinsic brittleness of $\mathrm{SiO}_{2 f} / \mathrm{SiO}_{2}$, usually, fusion welding is not applied because of the possibility of brittle fracture forming during cooling ${ }^{13}$. Alternatively, although adhesive bonding can be performed to realize $\mathrm{SiO}_{2 \mathrm{f}} / \mathrm{SiO}_{2}$-metal joint, the strength of the joint reduce during long service. Consequently, vacuum brazing is the primary method to joining $\mathrm{SiO}_{2 f} / \mathrm{SiO}_{2}$ to metals because of its cost-effectiveness and high-quality process ${ }^{14-22}$. However, two crucial challenges: the poor wettability of $\mathrm{SiO}_{2 \mathrm{f}} / \mathrm{SiO}_{2}$ and the high residual stress in the joint exist in brazing $\mathrm{SiO}_{2 \mathrm{f}} / \mathrm{SiO}_{2}$ to metal, which seriously impairs the strength of the joints. In view of that, some researchers demonstrated that the wettability of $\mathrm{SiO}_{2 \mathrm{f}} / \mathrm{SiO}_{2}$ with active brazing alloy can be successfully improved by coated nickel ${ }^{23}, \mathrm{CaCO}_{3}{ }^{24}$, or few-layer graphene ${ }^{25}$. Although the wettability of $\mathrm{SiO}_{2 \mathrm{f}} / \mathrm{SiO}_{2}$ with active brazing alloy is improved, a high-quality joint is difficult to obtain because of the negligence to the high residual stress.

So far, by micro-machine process on the surface of ceramic or composite, forming a 3D composite-metal gradient transition zone in their joints has been developed to reduce the residual stress of the brazed joints ${ }^{26-28}$. Zhang et al. ${ }^{26}$ demonstrated that fabricating microscale periodic surface pattern on $\mathrm{Al}_{2} \mathrm{O}_{3}$ ceramic surface was a promising method to form a $3 \mathrm{D}$ transition region and reduce the residual stress of ceramic-metal joints. Wang et al. ${ }^{27}$ reported that drilling holes on the surface of $\mathrm{C} / \mathrm{C}$ composite can reduce the residual stress because of constructing a 3D C/C-metal gradient transition zone in joint. Shen et al..$^{28}$ demonstrated that drilling blind holes on $\mathrm{C} / \mathrm{C}$ composite surface by means of laser can result in significantly strengthening and toughening the joint due to creating a $3 \mathrm{D}$ transition region between the $\mathrm{C} / \mathrm{C}$ and braze. To some extent, micro-machining on its surface can lead to damaging the whole structure of $\mathrm{SiO}_{2 f} / \mathrm{SiO}_{2}$, due to its intrinsic brittleness and braided structure. Undoubtedly, it is urgently to provide an effective method to both improving the wettability with active brazing alloy and forming a $3 \mathrm{D}$ gradient transition zone at $\mathrm{SiO}_{2 \mathrm{f}} / \mathrm{SiO}_{2}$ side without impairing the overall structure. 


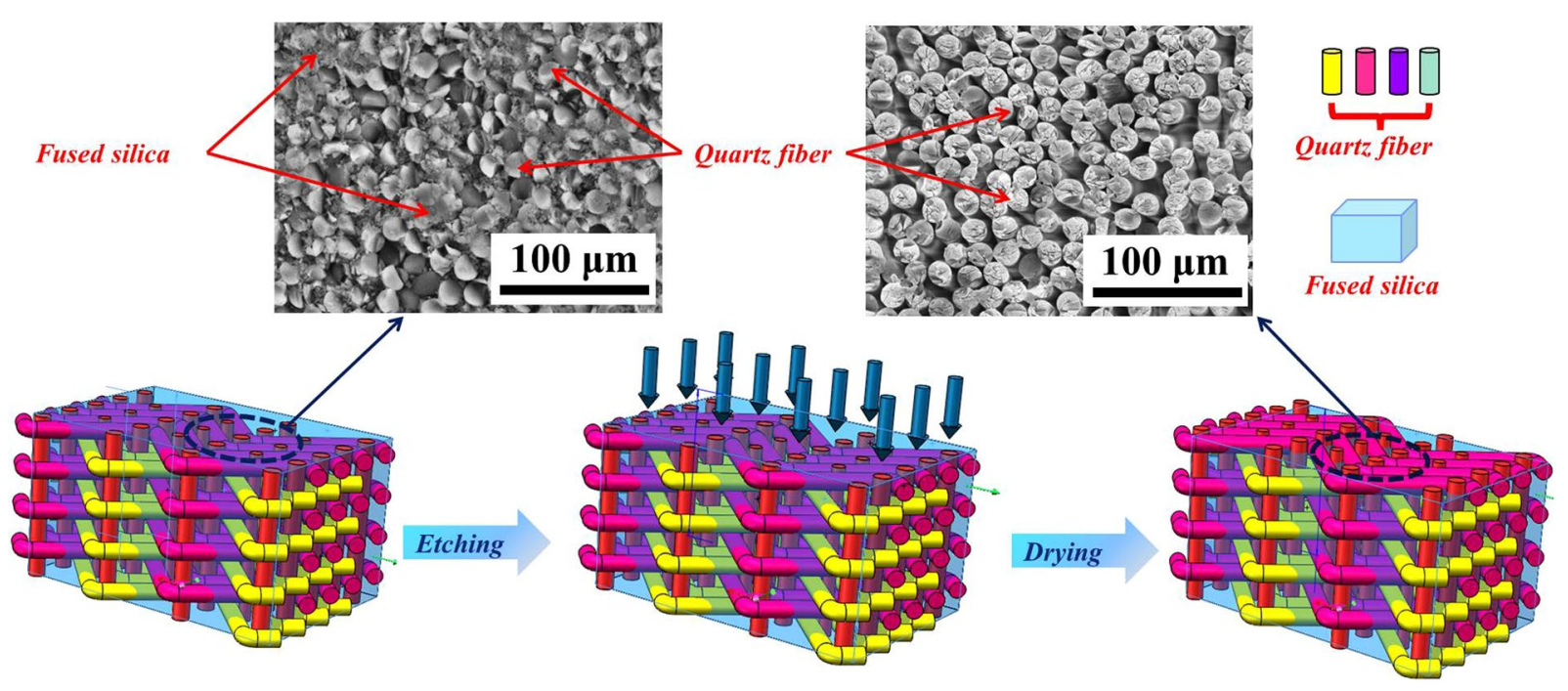

Figure 1. Schematic of etching treatment on $\mathrm{SiO}_{2 \mathrm{f}} / \mathrm{SiO}_{2}$.

Our latest work showed that a 3D-pinning structure was beneficial to the joint strength. However, the structure introduced the residual stress among the braided quartz fibers, which complicated the distribution of the residual stress in the joint. Furthermore, the complex structure of the $3 \mathrm{D} \mathrm{SiO} \mathrm{Sf}_{2} / \mathrm{SiO}_{2}$-metal gradient transition zone had a decisive influence on the mechanical property of joint. Thus, the relationship between the residual stress, the surface structure and joint property in the brazed joints need be explored in depth and in detail.

In this paper, the etching treatment with $\mathrm{HF}$ acid solution was designed to regulate the surface structure of $\mathrm{SiO}_{2 \mathrm{f}} / \mathrm{SiO}_{2}$. Finite element analysis (FEA) models were developed to study the relationship between the residual stress and the surface structure in the brazed joints, which can guide the subsequent experiment and provide the theoretical basis. Furthermore, the relationship between the residual stress, the surface structure and the joint property in the brazed joints was discussed in detail.

\section{Experimental procedures}

Materials. The 3D four-directional braided $\mathrm{SiO}_{2 \mathrm{f}} / \mathrm{SiO}_{2}{ }^{29}$ and commercially available Nb were used as the parent materials. The dimension of $\mathrm{SiO}_{2 f} / \mathrm{SiO}_{2}$ brazing specimen was $5 \mathrm{~mm} \times 5 \mathrm{~mm} \times 3 \mathrm{~mm}$. Nb was cut into $10 \mathrm{~mm} \times 10 \mathrm{~mm} \times 3 \mathrm{~mm}$ slices for the microstructure observation and $10 \mathrm{~mm} \times 15 \mathrm{~mm} \times 3 \mathrm{~mm}$ for shear tests, respectively. The active brazing alloy foil $\mathrm{Ag}-21 \mathrm{Cu}-4.5 \mathrm{Ti}$ (wt.\%) with a thickness of $200 \mu \mathrm{m}$ was used to braze $\mathrm{SiO}_{2 f} / \mathrm{SiO}_{2}$ and $\mathrm{Nb}$. The bonding surfaces of samples were ground up to 400 by $\mathrm{SiC}$ sandpaper. All materials were ultrasonically cleaned in acetone for $15 \mathrm{~min}$.

The etching treatment on the surface of $\mathrm{SiO}_{2 \mathrm{f}} / \mathrm{SiO}_{2}$ was performed with $20 \mathrm{wt}$.\% HF acid solution. The schematic of the etching process is shown in Fig. 1. Firstly, the HF acid solution was directly placed on the surface of $\mathrm{SiO}_{2 \mathrm{f}} / \mathrm{SiO}_{2}$ for a few seconds. Then, the surface was washed with deionized water carefully. Finally, $\mathrm{SiO}_{2 \mathrm{f}} / \mathrm{SiO}_{2}$ with etching treatment $\left(\mathrm{E}-\mathrm{SiO}_{2 \mathrm{f}} / \mathrm{SiO}_{2}\right)$ was obtained. In addition, by controlling etching process, the surface structure dimension can be tunable.

Wetting and brazing processes. Wetting experiments were performed using the sessile drop technique in which the alloys are placed on the substrate and the system is heated to $840^{\circ} \mathrm{C}$. For comparison, during the sessile drop experiments, AgCuTi brazing alloy foils were placed on $\mathrm{SiO}_{2 f} / \mathrm{SiO}_{2}$ with different infiltration depth, respectively. And the brazing experiments were performed with AgCuTi active brazing alloy foils between the parent materials. The structure of the assembly was $\mathrm{SiO}_{2 \mathrm{f}} / \mathrm{SiO}_{2} / \mathrm{AgCuTi} / \mathrm{Nb}$, and the assemblies were held by graphite jigs. In order to keep the specimens in close contact, a load of $0.01 \mathrm{MPa}$ was applied. The assemblies were heated to $840^{\circ} \mathrm{C}$ with a rate of $10^{\circ} \mathrm{C} \mathrm{m^{-1 }}$ in a vacuum furnace, isothermally held for $10 \mathrm{~min}$, and then cooled down to room temperature at a rate of $5^{\circ} \mathrm{C} \mathrm{min}^{-1}$.

The drop images, which were produced by an optical system coupled with a zoom (magnification $30 \times$ ), were recorded by a video camera connected to a computer, permitting automatic image analysis. This device enables the contact angles of the drop were measured with an accuracy of $\pm 2^{\circ}$. The interfacial microstructures of the joints were analyzed by a scanning electron microscopy (SEM) fitted with an energy dispersive spectroscopy (EDS). To identify the phases formed in the reaction layers adjacent to $\mathrm{SiO}_{2 \mathrm{f}} / \mathrm{SiO}_{2}$ and fracture, a JDX-3530M $\mathrm{X}$-ray diffraction (XRD) was used. To evaluate the mechanical properties of the joints, shear tests were carried out using an Instron-1186 universal testing machine at room temperature. The average stress strength was identified by five shear specimens brazed under the same condition.

FEA calculations. The FEA method was employed to investigate the distribution of the residual stress along the $\mathrm{SiO}_{2 f} / \mathrm{SiO}_{2}-\mathrm{Nb}$ brazed joint in our research, because the method was proved to be a useful tool for predicting residual stress in the joint ${ }^{30,31}$. Thus, in this paper, the distribution of the residual stress, which yielded in the 

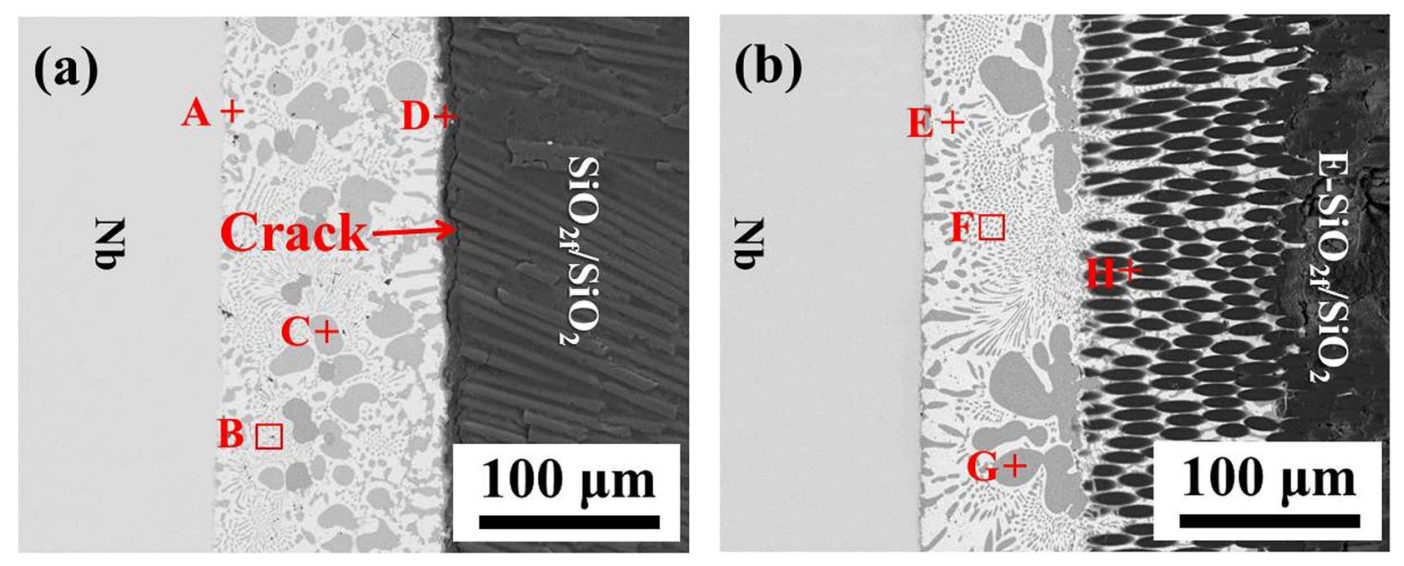

Figure 2. $\mathrm{SEM}$ images of (a) $\mathrm{SiO}_{2 \mathrm{f}} / \mathrm{SiO}_{2}-\mathrm{Nb}$ and (b) $\mathrm{E}-\mathrm{SiO}_{2 \mathrm{f}} / \mathrm{SiO}_{2}-\mathrm{Nb}$ joint.

joint during cooling due to the mismatch of Coefficient Thermal Expansion (CTE), was simulated by FEA with Marc-2013.

\section{Results and Discussion}

Microstructure of the joint brazed with and without etching treatment. The interface analysis was first performed on the brazing joints before and after etching treatment, evidencing the establishment and the application of model for FEA. The typical microstructure of $\mathrm{SiO}_{2 \mathrm{f}} / \mathrm{SiO}_{2}-\mathrm{Nb}$ joint is shown in Fig. 2a. It can be found cracks formed at $\mathrm{SiO}_{2 \mathrm{f}} / \mathrm{SiO}_{2}$ side, which the typical interface structure of the joint was $\mathrm{SiO}_{2 \mathrm{f}} /$ $\mathrm{SiO}_{2} / \mathrm{Ag}(\mathrm{s}, \mathrm{s})+\mathrm{Cu}(\mathrm{s}, \mathrm{s}) / \mathrm{Cu}_{3} \mathrm{Ti}_{3} \mathrm{O} / \mathrm{TiSi}_{2}$, based on our latest research. And the mismatch of CTE between $\mathrm{SiO}_{2 \mathrm{f}} / \mathrm{SiO}_{2}\left(\mathrm{CTE}_{\mathrm{SiO} 2 \mathrm{f} / \mathrm{SiO} 2}=\sim 2.0 \times 10^{-6} / \mathrm{K}\right)$ and $\mathrm{Nb}\left(\mathrm{CTE}_{\mathrm{Nb}}=\sim 7 \times 10^{-6} / \mathrm{K}\right)$ or AgCuTi active brazing alloy $\left(\mathrm{CTE}_{\mathrm{AgCuTi}}=\sim 15.4 \times 10^{-6} / \mathrm{K}\right)$ is high, which results in forming cracks ${ }^{32}$. Figure $2 \mathrm{~b}$ shows the typical microstructure of $\mathrm{E}-\mathrm{SiO}_{2 \mathrm{f}} / \mathrm{SiO}_{2}-\mathrm{Nb}$ joint. Compared with $\mathrm{SiO}_{2 \mathrm{f}} / \mathrm{SiO}_{2}-\mathrm{Nb}$ joint, the primary compositions of beam were nearly same. The brazing alloy infiltrated into $\mathrm{E}-\mathrm{SiO}_{2 \mathrm{f}} / \mathrm{SiO}_{2}$ and formed a "3D-pinning structure", which contributed to form a good CTE gradient transition and to reduce its mismatch between different materials ${ }^{27,33}$. Consequently, the joint exhibited sound bonding without any defect and crack.

In order to further investigate the interfacial microstructure of the $\mathrm{E}-\mathrm{SiO}_{2 \mathrm{f}} / \mathrm{SiO}_{2}-\mathrm{Nb}$ joint, the main elements distribution of the joint produced at $840^{\circ} \mathrm{C}$ for $10 \mathrm{~min}$ are analyzed, as shown in Fig. 3. The Fig. 3a clearly presents that a sound joint has been obtained. Figure $3 \mathrm{~b}-\mathrm{f}$ shows the distribution of $\mathrm{Ag}, \mathrm{Cu}, \mathrm{Ti}, \mathrm{Si}$ and $\mathrm{Nb}$, respectively. It can be seen that the $\mathrm{Si}$ had a strong tendency to extremely react with $\mathrm{Ti}$, as shown in Fig. $3 \mathrm{~d}$ and e. In addition, notice that Ti-rich granular were formed adjacent to $\mathrm{SiO}_{2 f} / \mathrm{SiO}_{2}$ composite, revealed that Ti segregated in 3D $\mathrm{SiO}_{2 \mathrm{f}} / \mathrm{SiO}_{2}$-metal gradient transition zone. Furthermore, the distribution of $\mathrm{Ti}$ in that zone was not even because the brazing alloy gradually infiltrated into $\mathrm{E}-\mathrm{SiO}_{2 f} / \mathrm{SiO}_{2}$, and Ti reacted with the contacted quartz fibers. Thus, the remaining Ti became less and less as the infiltration depth increasing. Moreover, it was important to note that $\mathrm{SiO}_{2 \mathrm{f}} / \mathrm{SiO}_{2}$ and $\mathrm{Nb}$ did not spread or dissolve during brazing, as shown in Fig. $3 \mathrm{~b}$ and $\mathrm{f}$, respectively. Therefore, based on the above results, the model for FEA can be developed as three parts: $\mathrm{SiO}_{2 f} / \mathrm{SiO}_{2}$ (or E-SiO $\mathrm{Si}_{2} / \mathrm{SiO}_{2}$ ), $\mathrm{AgCuTi}$ brazing alloy and $\mathrm{Nb}$ (see Fig. 4). It was worth noting that the special structure of the $\mathrm{E}-\mathrm{SiO}_{2 \mathrm{f}} / \mathrm{SiO}_{2}$ by the etching treatment needed a completely new design system (Details on the model were shown in supplementary material).

Estimation of residual stress in the brazed joint using FEA. Recently, many researches have focused on reducing the residual stress in the composite/ceramic and metal brazed joints ${ }^{34-37}$. In fact, it is very difficult to measure the residual stress of the brazed joints directly through the experimental measurement. Thus, it is general to analyze the residual stress of the brazed joints from the joint fracture path. However, this analysis only horizontal contrast (trend), cannot be quantified (experimental value) contrast. In addition, when the fracture path exists in the same area, it is difficult to analyze the residual stress of composite/ceramic and metal brazed joints. In order to analyze the residual stress variation better, some researchers always investigated the distribution of residual stress by Finite Element Analysis (FEA) ${ }^{38,39}$. In our case, the fracture path is different before and after etching treatment ${ }^{40}$. Especially, after etching treatment, fractures all exist close to the etching area, then it is not accurate to analyze the residual stress through the fracture path. Therefore, based on the typical experimental results, the values of residual stress of the samples with varied etching depth can be examined by FEA method.

Based on the analysis in 3.1 section, the FEA was applied to simulate the distribution of residual stress in the brazed joint, and the details on simulation process were shown in supplementary material. The etching depth was related to the dimension of "3D-pinning structure" which directly affected the residual stress in the joint. Therefore, it is important to investigate the relationship between the surface structure (that is the layer thickness of 3D-pinning structure) and the residual stress in a brazed joint, which can provide the theoretical basis for the following brazing experiments.

Figure 5 shows the distribution of equivalent von mises stress in $0 \mu \mathrm{m} @ \mathrm{E}-\mathrm{SiO}_{2 \mathrm{f}} / \mathrm{SiO}_{2}-\mathrm{Nb}$ (denoted as "X $\mu \mathrm{m} @ \mathrm{E}-\mathrm{SiO}_{2 \mathrm{f}} / \mathrm{SiO}_{2}-\mathrm{Nb}$ for convenience, X represented the etching depth), $50 \mu \mathrm{m} @ \mathrm{E}-\mathrm{SiO}_{2 \mathrm{f}} / \mathrm{SiO}_{2}-\mathrm{Nb}$, $75 \mu \mathrm{m} @ \mathrm{E}-\mathrm{SiO}_{2 \mathrm{f}} / \mathrm{SiO}_{2}-\mathrm{Nb}, 100 \mu \mathrm{m} @ \mathrm{E}-\mathrm{SiO}_{2 \mathrm{f}} / \mathrm{SiO}_{2}-\mathrm{Nb}, 125 \mu \mathrm{m} @ \mathrm{E}-\mathrm{SiO}_{2 \mathrm{f}} / \mathrm{SiO}_{2}-\mathrm{Nb}$ and $150 \mu \mathrm{m} @ \mathrm{E}-\mathrm{SiO}_{2 \mathrm{f}} / \mathrm{SiO}{ }_{2}-\mathrm{Nb}$ 

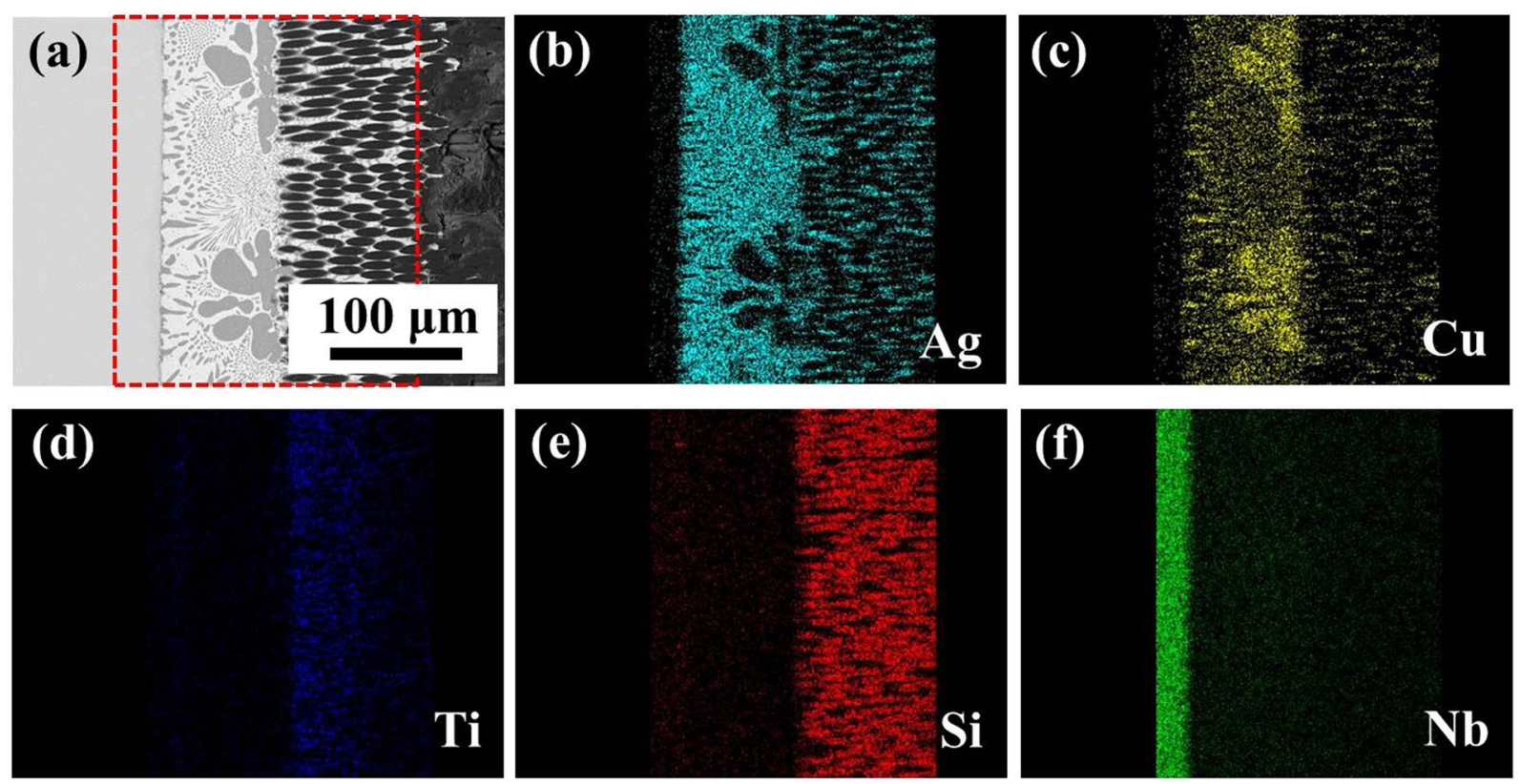

Figure 3. Interfacial microstructure and elemental distribution of $\mathrm{E}-\mathrm{SiO}_{2 \mathrm{f}} / \mathrm{SiO}_{2}-\mathrm{Nb}$ joint (a) $\mathrm{BSE}$ image of the joint and EDS maps of (b) Ag, (c) Cu, (d) Ti, (e) Si and (f) Nb.

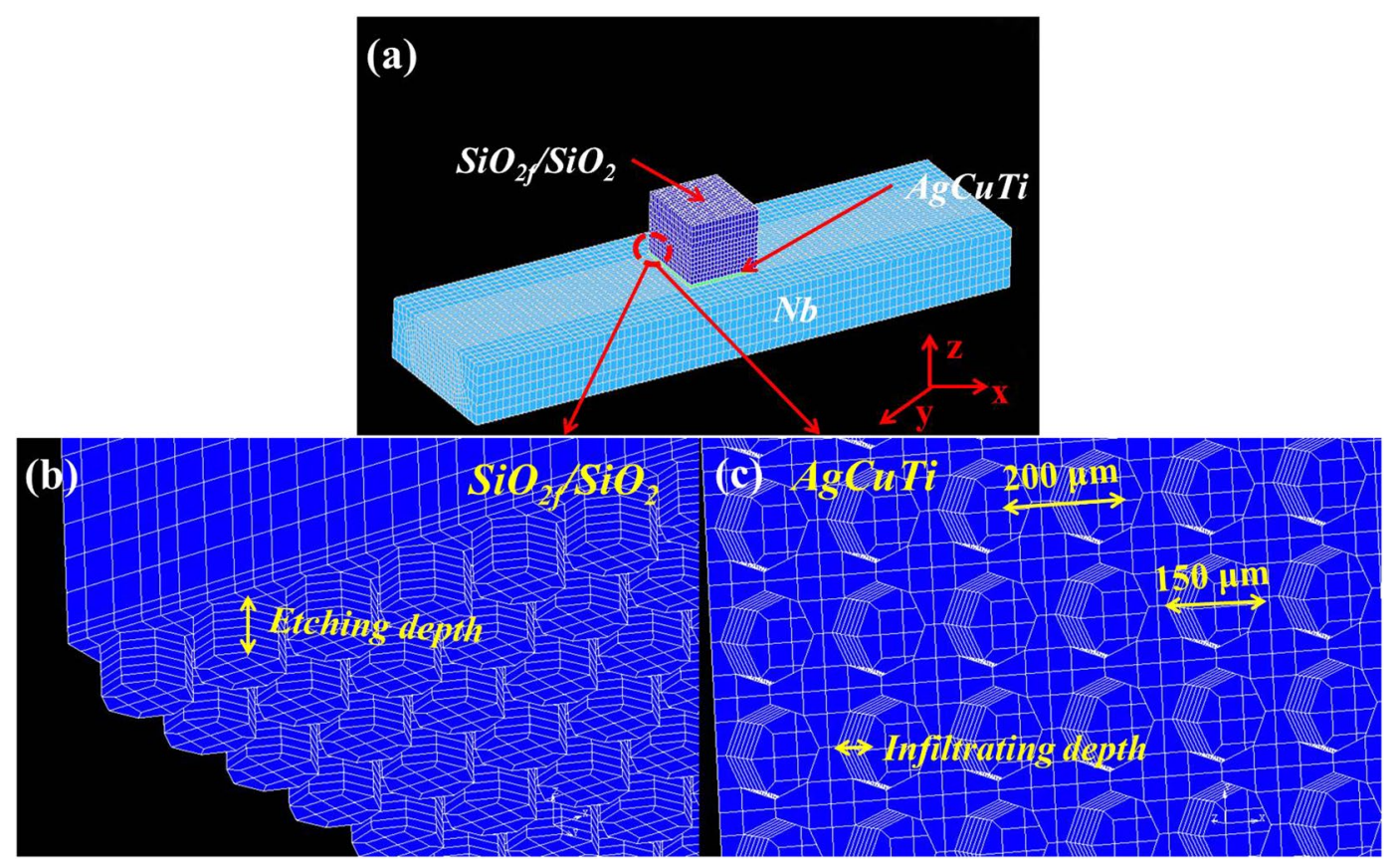

Figure 4. Mesh of finite elements for (a) the brazed joint, (b) magnification of the $\mathrm{E}-\mathrm{SiO}_{2 \mathrm{f}} / \mathrm{SiO}_{2}$, (c) magnification of AgCuTi brazing alloy.

joints brazed by $\mathrm{AgCuTi}$ at $840^{\circ} \mathrm{C}$ for $10 \mathrm{~min}$. It is obvious that the residual stress has been gradually changed with the etching depth increasing from $0 \mu \mathrm{m}$ to $150 \mu \mathrm{m}$. As for $0 \mu \mathrm{m} @ \mathrm{E}-\mathrm{SiO}_{2 \mathrm{f}} / \mathrm{SiO}_{2}-\mathrm{Nb}$ joint (that is $\mathrm{SiO}_{2 \mathrm{f}} / \mathrm{SiO}_{2}-\mathrm{Nb}$ joint), the residual stress is constrained around the $0 \mu \mathrm{m} @ \mathrm{E}-\mathrm{SiO}_{2 \mathrm{f}} / \mathrm{SiO}_{2}-\mathrm{AgCuTi}$ interface, and the peak residual stress of $380 \mathrm{MPa}$ (see Fig. 6) generates in the $\mathrm{SiO}_{2 \mathrm{f}} / \mathrm{SiO}_{2}$ side close to brazing alloy, and then gradually decreased along the vertical direction of $0 \mu \mathrm{m} @ \mathrm{E}-\mathrm{SiO}_{2 \mathrm{f}} / \mathrm{SiO}_{2}$-AgCuTi interface. After etching treatment, the higher residual stress in $\mathrm{E}_{-} \mathrm{SiO}_{2 \mathrm{f}} / \mathrm{SiO}_{2}-\mathrm{Nb}$ joints has transferred in the "3D-pinning structure", which suggested that the structure played a key role in the distribution of the residual stress in the joints (see Fig. 5b-f). Moreover, it is worth noting that the maximum residual stress of $\mathrm{E}-\mathrm{SiO}_{2 f} / \mathrm{SiO}_{2}-\mathrm{Nb}$ joints has transferred on the braided quartz fibers in the "3D-pinning structure", as shown in Fig. 5b-f. Furthermore, it clearly presents that the residual stress in the joints and on the braided quartz fibers were both reduced with the etching depth increasing. However, when the etching depth was too thick, the residual stress increased significantly, especially on the braided quartz fibers, as shown 

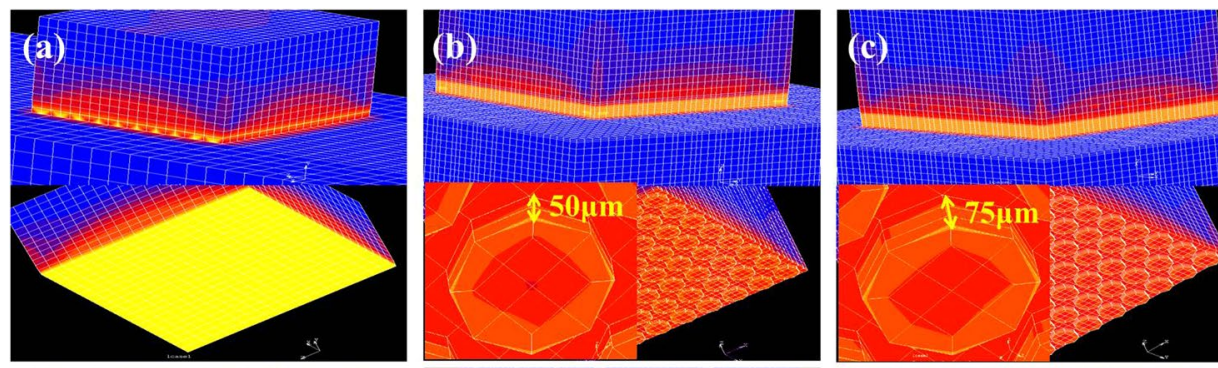

$380 \mathrm{MPa}$
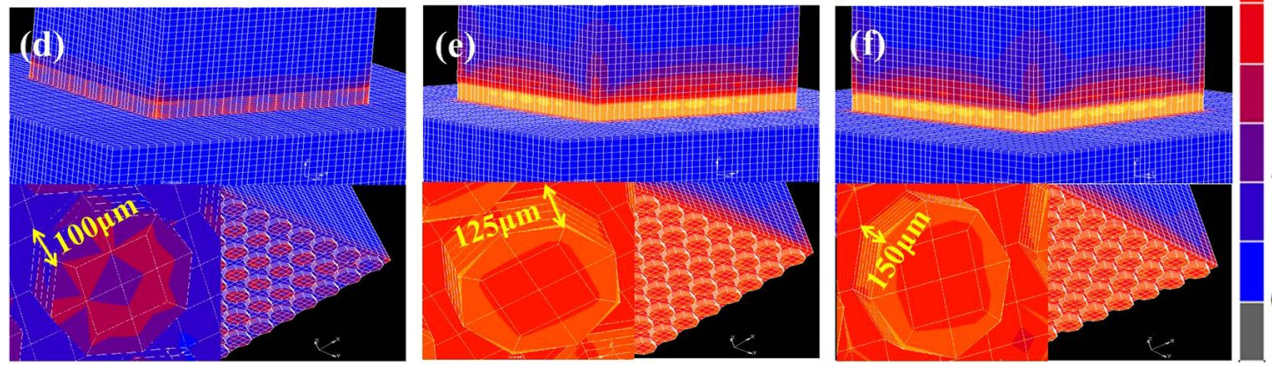

$152 \mathrm{MPa}$

$76 \mathrm{MPa}$

Figure 5. Distribution of equivalent von mises stress in (a) $0 \mu \mathrm{m} @ \mathrm{E}-\mathrm{SiO}_{2 \mathrm{f}} / \mathrm{SiO}_{2}-\mathrm{Nb},(\mathbf{b}) 50 \mu \mathrm{m} @ \mathrm{E}-\mathrm{SiO}_{2 \mathrm{f}} /$ $\mathrm{SiO}_{2}-\mathrm{Nb},(\mathbf{c}) 75 \mu \mathrm{m} @ \mathrm{E}-\mathrm{SiO}_{2 \mathrm{f}} / \mathrm{SiO}_{2}-\mathrm{Nb},(\mathbf{d}) 100 \mu \mathrm{m} @ \mathrm{E}-\mathrm{SiO}_{2 \mathrm{f}} / \mathrm{SiO}_{2}-\mathrm{Nb},(\mathbf{e}) 125 \mu \mathrm{m} @ \mathrm{E}-\mathrm{SiO}_{2 \mathrm{f}} / \mathrm{SiO}_{2}-\mathrm{Nb}$ and (f) $150 \mu \mathrm{m} @ \mathrm{E}-\mathrm{SiO}_{2 \mathrm{f}} / \mathrm{SiO}_{2}-\mathrm{Nb}$ joint.

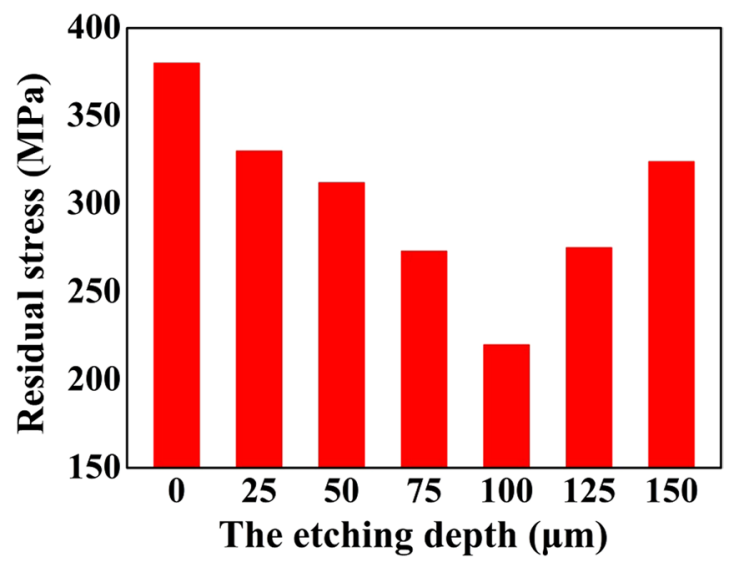

Figure 6. Comparison of equivalent von mises stress for different etching depth.

in Fig. 5d-f. From the above results, it can be inferred that the "3D-pinning structure" can effectively reduce the residual stress and change the distribution of residual stress in the joints.

As for the $0 \mu \mathrm{m} @ \mathrm{E}-\mathrm{SiO}_{2 \mathrm{f}} / \mathrm{SiO}_{2}-\mathrm{Nb}$ joints, the high CTE mismatch may cause the residual stress constraining around the $\mathrm{SiO}_{2 \mathrm{f}} / \mathrm{SiO}_{2}$-AgCuTi interface. After etching treatment, a "3D-pinning structure" formed in the joint, which was contributed the brazing alloy infiltrating into the $\mathrm{E}-\mathrm{SiO}_{2 \mathrm{f}} / \mathrm{SiO}_{2}$ side, forming a $3 \mathrm{D} \mathrm{SiO} \mathrm{S}_{2} / \mathrm{SiO}_{2}$-metal gradient transition zone. The zone was beneficial to reduce the residual stress induced by the high mismatch of the dissimilar substrates. However, the zone also made the distribution of the residual stress in "3D-pinning structure" complicated, as shown in Fig. 5. In particular, when the etching depth further increased, the residual stress rather than reduced. In order to analyses the reason, we explored the relationship between the residual stress of joint in different directions and surface structure of the $\mathrm{E}-\mathrm{SiO}_{2 \mathrm{f}} / \mathrm{SiO}_{2}$ by $\mathrm{FEA}$. The schematic diagram of the profile of the model used in simulation procedure is shown in Fig. 7a. According to the structure of the $\mathrm{E}-\mathrm{SiO}_{2 \mathrm{f}} / \mathrm{SiO}_{2}-\mathrm{Nb}$ joints and our calculation results, it can be inferred that principal stress $\sigma_{\mathrm{z}}$ changed with the etching depth increasing, but $\sigma_{\mathrm{x}}$ and $\sigma_{\mathrm{y}}$ did not or very little change. Another significant stress was shear stress $\tau_{x y}$, which latter, in combination with $\sigma_{z}$, can induce fracture of the quartz fibers ${ }^{41}$. In addition, shear stress $\tau_{x z}$ and $\tau_{z y}$ changed very little with the etching depth increasing. So, the following analysis only focused on the largest principal stress $\sigma_{\mathrm{z}}$ and shear stress $\tau_{\mathrm{xy}}$ in $\mathrm{E}-\mathrm{SiO}_{2 \mathrm{f}} / \mathrm{SiO}_{2}-\mathrm{Nb}$ joints. Figure $7 \mathrm{~b}$ and c show the maximal $\sigma_{\mathrm{z}}$ and $\tau_{\mathrm{xy}}$ in zone $\mathrm{A}$ of $\mathrm{E}-\mathrm{SiO}_{2 \mathrm{f}} / \mathrm{SiO}_{2}-\mathrm{Nb}$ joints, respectively. It can be observed that after etching treatment, $\sigma_{\mathrm{z}}$ reduced markedly (from 0 to $100 \mu \mathrm{m}$ ), but a little varied with the etching depth increasing to $150 \mu \mathrm{m}$, as shown in Fig. $7 \mathrm{~b}$. In contrast, it is noteworthy that $\tau_{\mathrm{xy}}$ significantly increased with the etching depth further increasing (from 100 to $150 \mu \mathrm{m}$ ), as shown in Fig. 7c. Thus, the maximal resultant force in the zone descended first (from 0 to $100 \mu \mathrm{m}$ ) and then ascended (from 100 to $150 \mu \mathrm{m}$ ), as shown in Fig. 6. From the above results, it can be concluded that with the 
(a)

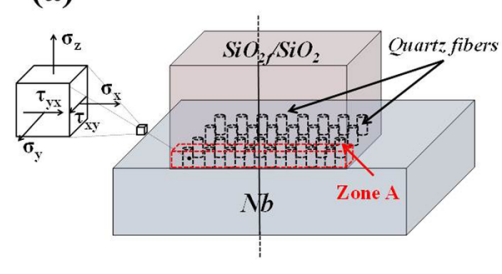

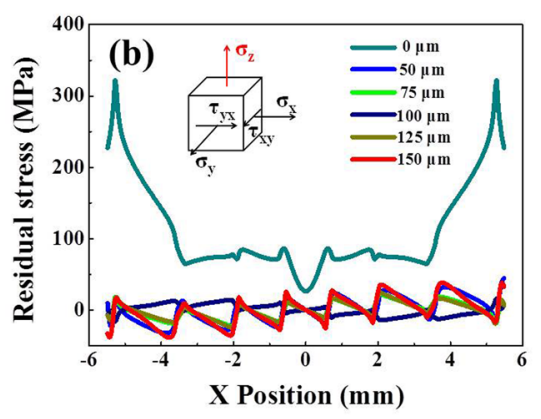

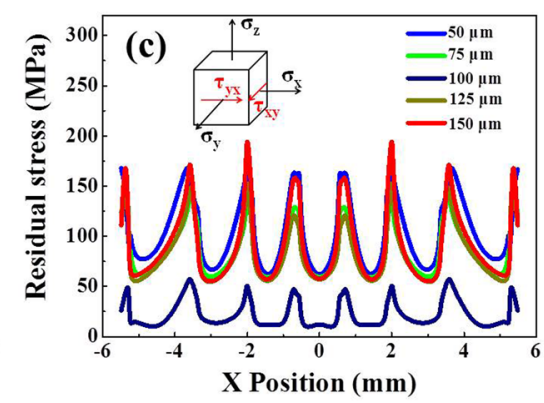

Figure 7. (a) Schematic diagram of model and coordinate half system adopted in calculation and residual stress distribution of $\mathrm{SiO}_{2 f} / \mathrm{SiO}_{2}$ side closed to interface $(\mathbf{b}) \sigma_{\mathrm{z}},(\mathbf{c}) \tau_{\mathrm{xy}}$

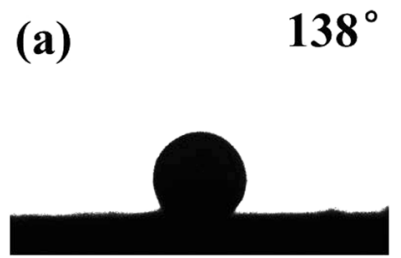

(d)

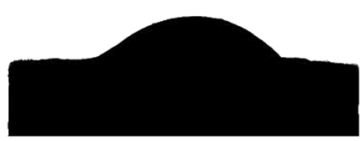

(b)

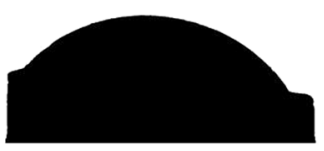

(e)

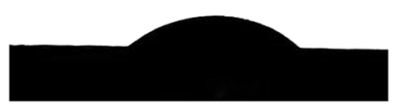

(c)

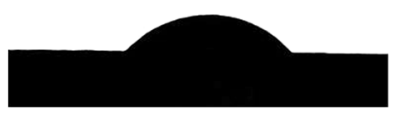

(f)

$36^{\circ}$

Figure 8. Contact angles of AgCuTi brazing alloy on the (a) $0 \mu \mathrm{m} @ \mathrm{E}-\mathrm{SiO}_{2 \mathrm{f}} / \mathrm{SiO}_{2}$, (b) $50 \mu \mathrm{m} @ \mathrm{E}-\mathrm{SiO}_{2 \mathrm{f}} / \mathrm{SiO}_{2},(\mathbf{c})$ $75 \mu \mathrm{m} @ \mathrm{E}-\mathrm{SiO}_{2 \mathrm{f}} / \mathrm{SiO}_{2}$, (d) $100 \mu \mathrm{m} @ \mathrm{E}-\mathrm{SiO}_{2 \mathrm{f}} / \mathrm{SiO}_{2}$, (e) $125 \mu \mathrm{m} @ \mathrm{E}-\mathrm{SiO}_{2 \mathrm{f}} / \mathrm{SiO}_{2}$ and (f) $150 \mu \mathrm{m} @ \mathrm{E}-\mathrm{SiO}_{2 \mathrm{f}} / \mathrm{SiO}_{2}$.

etching depth between 0 to $100 \mu \mathrm{m}$, the residual stress of the joint can be reduced, because of the formed $3 \mathrm{D} \mathrm{SiO} \mathrm{S}_{2} f$ $\mathrm{SiO}_{2}$-metal gradient transition zone, which was contributed to decrease the CTE mismatch. Nevertheless, with the etching depth further increasing (from 100 to $150 \mu \mathrm{m}$ ), the residual stress was no lower, but higher, due to the $\tau_{x y}$ which was introduced by the zone and posed serious problems for the joint. Therefore, it can be concluded that although the "3D-pinning structure" can reduce the residual stress, the dimension of the structure should be in proper domain.

Effect of surface structure on the wettability of $\mathrm{SiO}_{2 \mathrm{f}} / \mathrm{SiO}_{2}$ composite. It is well known that the wettability of $\mathrm{SiO}_{2 \mathrm{f}} / \mathrm{SiO}_{2}$ plays an important role in obtaining a high-quality brazing joint ${ }^{42,43}$. Therefore, it is necessary to investigate the effect of etching treatment on the wettability of AgCuTi brazing alloy on $\mathrm{SiO}_{2 \mathrm{f}} / \mathrm{SiO}_{2}$ surface. Figure 8 shows the contact angles (CA) of AgCuTi brazing alloy on the surface of $0 \mu \mathrm{m} @ \mathrm{E}-\mathrm{SiO}_{2 \mathrm{f}} / \mathrm{SiO}_{2}$, $50 \mu \mathrm{m} @ \mathrm{E}-\mathrm{SiO}_{2 \mathrm{f}} / \mathrm{SiO}_{2}, 75 \mu \mathrm{m} @ \mathrm{E}-\mathrm{SiO}_{2 \mathrm{f}} / \mathrm{SiO}_{2}, 100 \mu \mathrm{m} @ \mathrm{E}-\mathrm{SiO}_{2 \mathrm{f}} / \mathrm{SiO}_{2}, 125 \mu \mathrm{m} @ \mathrm{E}-\mathrm{SiO}_{2 \mathrm{f}} / \mathrm{SiO}_{2}$ and $150 \mu \mathrm{m} @ \mathrm{E}-\mathrm{SiO}_{2 \mathrm{f}} /$ $\mathrm{SiO}_{2}$, respectively. It can been observed that the brazing alloy on $\mathrm{SiO}_{2 \mathrm{f}} / \mathrm{SiO}_{2}$ shows unsymmetrical round shape, with left side showing smaller contact angles compare to the right one. And there are two main reasons for it. Firstly, the $\mathrm{SiO}_{2 \mathrm{f}} / \mathrm{SiO}_{2}$ brazing specimen was obtained through cutting into slices and grounding the bonding surface. So, after that treatment, the bonding surface of $\mathrm{SiO}_{2 \mathrm{f}} / \mathrm{SiO}_{2}$ was not flat, which led to the surface of $\mathrm{E}-\mathrm{SiO}_{2 \mathrm{f}} /$ $\mathrm{SiO}_{2}$ uneven, even the slope. Secondly, the surface stability of liquid brazing alloy on $\mathrm{E}-\mathrm{SiO}_{2 \mathrm{f}} / \mathrm{SiO}_{2}$ was affected in vacuum furnace by mechanical pump and molecular pump during vacuumizing. Therefore, the brazing alloy on the surface of $\mathrm{E}-\mathrm{SiO}_{2 \mathrm{f}} / \mathrm{SiO}_{2}$ showed unsymmetrical round shape in Fig. 8. However, the left contact angles (CA) of $\mathrm{AgCuTi}$ brazing alloy on the $\mathrm{E}-\mathrm{SiO}_{2 \mathrm{f}} / \mathrm{SiO}_{2}$ decreased from $134^{\circ}$ to $32^{\circ}$ and the right $\mathrm{CA}$ decreased from $138^{\circ}$ to $36^{\circ}$, as shown in Fig. 2. The CA decreased with the etching depth increasing, though the brazing alloy on $\mathrm{SiO}_{2 \mathrm{f}} \mathrm{f}$ $\mathrm{SiO}_{2}$ shows unsymmetrical round shape. Then, in our case, the right CA acted as the evaluation standard.

Figure 8a shows the CA of AgCuTi brazing alloy on the surface of $\mathrm{SiO}_{2 \mathrm{f}} / \mathrm{SiO}_{2}$ was up to $138^{\circ}$, indicating poor wettability. After etching treatment, Fig. 8b shows the CA of AgCuTi brazing alloy on the $50 \mu \mathrm{m} @ \mathrm{E}-\mathrm{SiO}_{2 \mathrm{f}} \mathrm{I}$ $\mathrm{SiO}_{2}$ was significantly decreased to $53^{\circ}$, meaning favorable wettability. Furthermore, it can be seen that the CA decreased from $53^{\circ}$ to $36^{\circ}$ with the etching depth increasing. As a result, it suggested that after etching treatment, the wettability of all $\mathrm{E}-\mathrm{SiO}_{2 \mathrm{f}} / \mathrm{SiO}_{2}$ was excellent. In order to further explore the reasons for the improving wettability, the microstructures of wetting region were analyzed in details, as shown in Fig. 9. From Fig. 9a, it can be observed the weak joining between $\mathrm{SiO}_{2 \mathrm{f}} / \mathrm{SiO}_{2}$ and brazing alloy, because of the poor wettability of $\mathrm{SiO}_{2 \mathrm{f}} / \mathrm{SiO}_{2}$. In contrast, it can be observed that after etching treatment, the brazing alloy infiltrated into $\mathrm{E}-\mathrm{SiO}_{2 \mathrm{f}} / \mathrm{SiO}_{2}$ and sound metallurgical bonding was formed between brazing alloy and braided quartz fibers (see Fig. 9b). Furthermore, 

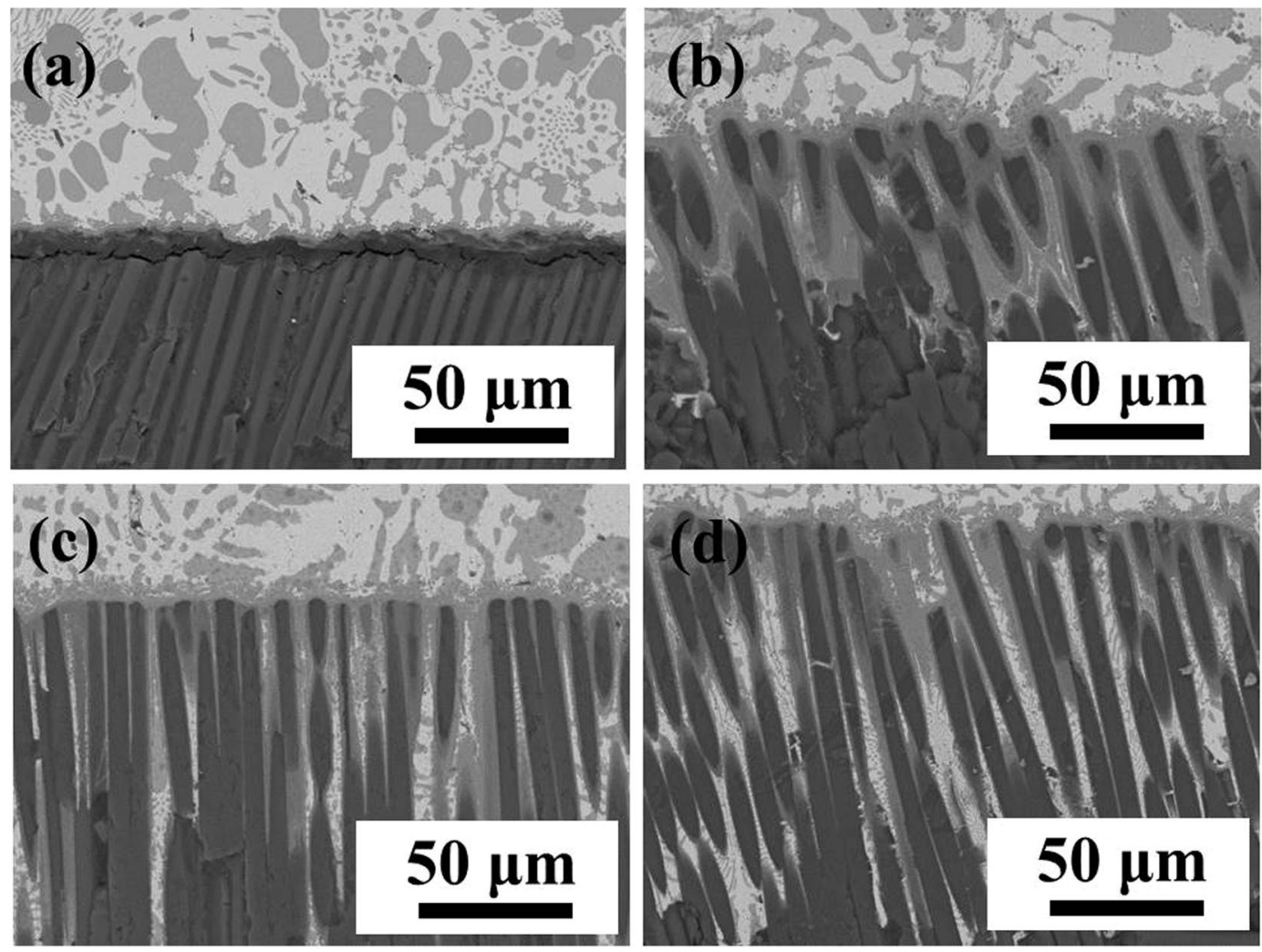

Figure 9. SEM images of wetting region in (a) $0 \mu \mathrm{m} @ \mathrm{E}-\mathrm{SiO}_{2 \mathrm{f}} / \mathrm{SiO} \mathrm{O}_{2}$, (b) $50 \mu \mathrm{m} @ \mathrm{E}-\mathrm{SiO}_{2 \mathrm{f}} / \mathrm{SiO}_{2}$, (c) $100 \mu \mathrm{m} @ \mathrm{E}-$ $\mathrm{SiO}_{2 \mathrm{f}} / \mathrm{SiO}_{2}$ and (d) $150 \mu \mathrm{m} @ \mathrm{E}-\mathrm{SiO}_{2 \mathrm{f}} / \mathrm{SiO}_{2}$.

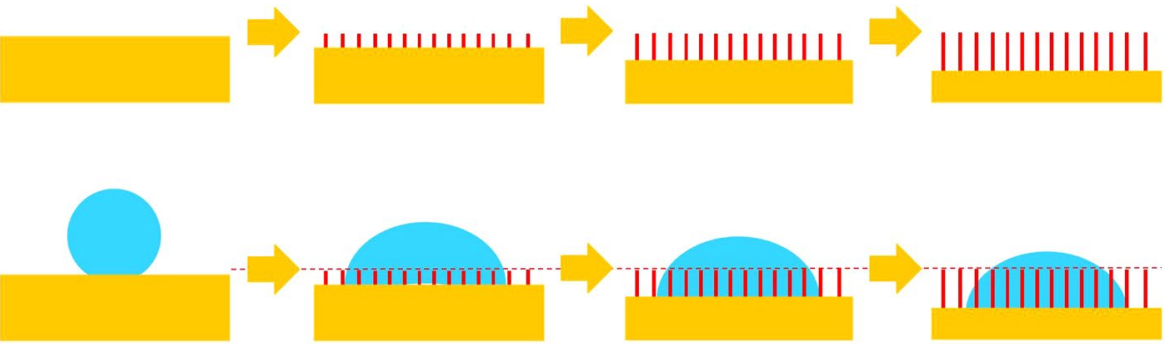

Figure 10. Schematic of wetting evolution process.

the infiltration depth was gradually increased with etching depth increasing, as shown in Fig. 9. After etching treatment, only the silica sol was consumed and numerous quartz fibers were left on the surface of $\mathrm{SiO}_{2 \mathrm{f}} / \mathrm{SiO}_{2}{ }^{17}$. Based on the above results, we believe that the poor wettability of $\mathrm{SiO}_{2 f} / \mathrm{SiO}_{2}$ can be owing to the silica sol, and the wettability between brazing alloy and quartz fibers was extremely well. It suggested that the etching treatment was an easy and effective way to improve the wettability of $\mathrm{SiO}_{2 \mathrm{f}} / \mathrm{SiO}_{2}$. Thus, it can be inferred that the space of the consumed silica sol was able to be filled up with sufficient brazing alloy.

Generally, the wettability of the materials with the same surface state is almost identical under the same condition. The surface of $\mathrm{SiO}_{2 f} / \mathrm{SiO}_{2}$, after etching treatment, is all the quartz fibers were left, which are the same regardless of the etching depth. However, it is worth noting that the CA of AgCuTi brazing alloy on the surface of $\mathrm{E}-\mathrm{SiO}_{2 \mathrm{f}} / \mathrm{SiO}_{2}$ decreased with the etching depth increasing, as shown in Fig. 8. In order to illustrate the wetting process, a concept physical model was established, as shown in Fig. 10. After etching treatment, the fused silica was consumed and quartz fibers were left in the transition zone, which contributed to the brazing alloy infiltrating into $\mathrm{E}-\mathrm{SiO}_{2 \mathrm{f}} / \mathrm{SiO}_{2}$. Furthermore, the width of the transition zone increased with the etching depth increasing, and then less and less brazing alloy was left on the surface of $\mathrm{E}-\mathrm{SiO}_{2 f} / \mathrm{SiO}_{2}$, as shown in Fig. 10. Thus, the CA of $\mathrm{E}-\mathrm{SiO}_{2 \mathrm{f}} / \mathrm{SiO}_{2}$ decreased with etching depth increasing from the wetting experiments results. In fact, the CA of $\mathrm{E}-\mathrm{SiO}_{2 \mathrm{f}} / \mathrm{SiO}_{2}$ was constant. According to the above results, it is reasonable to infer that the space of the consumed silica sol can be filled up with brazing alloy, as long as it was enough. 

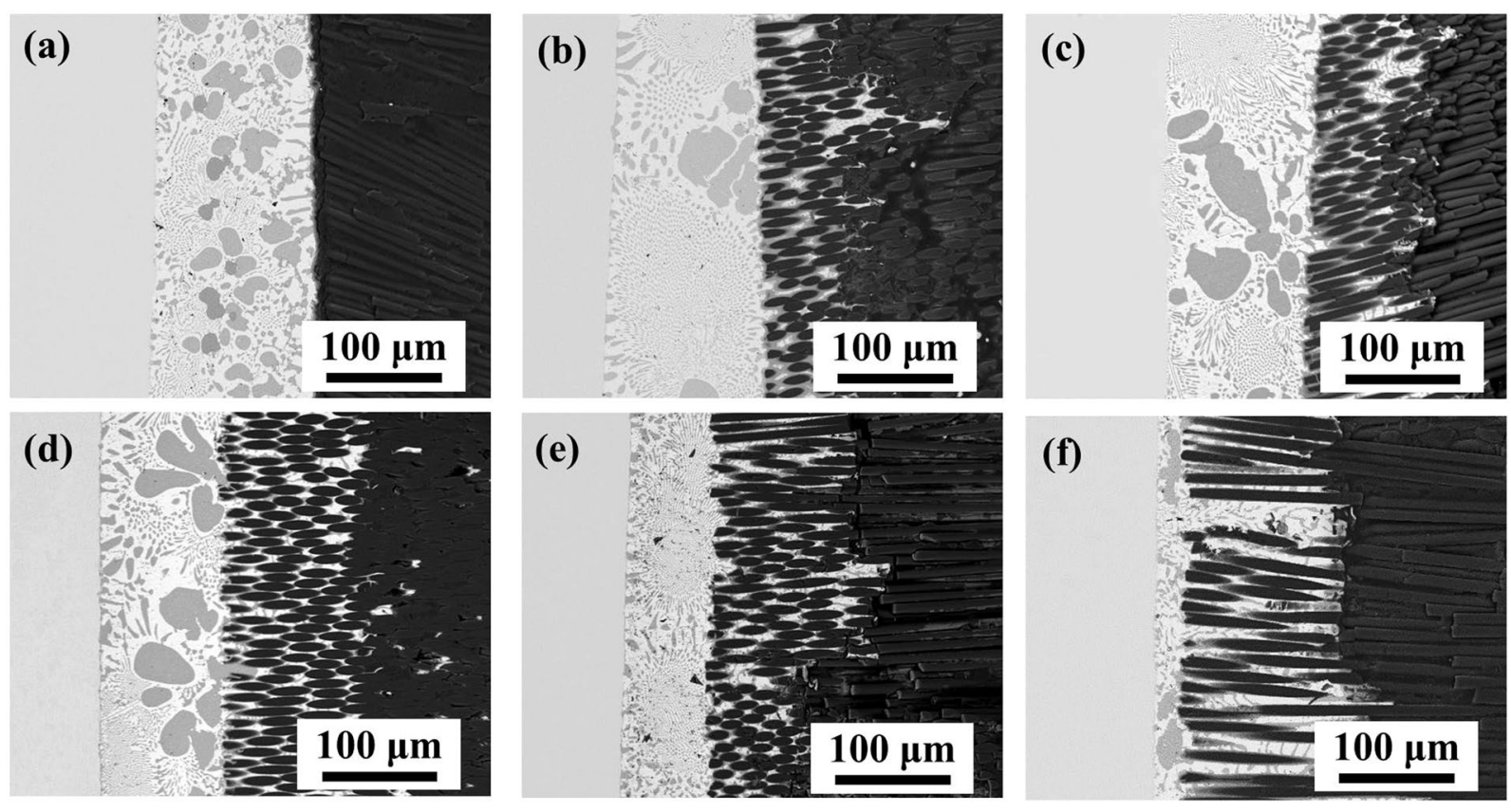

Figure 11. SEM images of (a) $0 \mu \mathrm{m} @ \mathrm{E}-\mathrm{SiO}_{2 \mathrm{f}} / \mathrm{SiO}_{2}-\mathrm{Nb}$, (b) $50 \mu \mathrm{m} @ \mathrm{E}-\mathrm{SiO}_{2 \mathrm{f}} / \mathrm{SiO}_{2}-\mathrm{Nb},(\mathbf{c}) 75 \mu \mathrm{m} @ \mathrm{E}-\mathrm{SiO}_{2 \mathrm{f}} /$ $\mathrm{SiO}_{2}-\mathrm{Nb},(\mathbf{d}) 100 \mu \mathrm{m} @ \mathrm{E}-\mathrm{SiO}_{2 \mathrm{f}} / \mathrm{SiO}_{2}-\mathrm{Nb},(\mathbf{e}) 125 \mu \mathrm{m} @ \mathrm{E}-\mathrm{SiO}_{2 \mathrm{f}} / \mathrm{SiO}_{2}-\mathrm{Nb}$ and (f) $150 \mu \mathrm{m} @ \mathrm{E}-\mathrm{SiO}_{2 \mathrm{f}} / \mathrm{SiO}_{2}-\mathrm{Nb}$ joint.

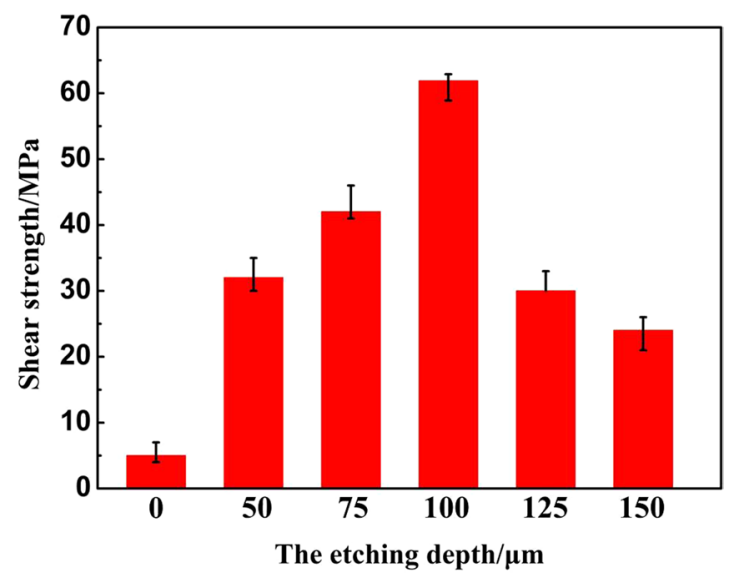

Figure 12. Shear strength of brazed joints with different interfacial structure.

Effect of surface structure of $\mathrm{SiO}_{2 f} / \mathrm{SiO}_{2}$ on the joint microstructure and property. In order to further investigate the relationship between the residual stress, the surface structure and the joint property in the brazed joints, the joining strength and the microstructure evolution was comparatively studied. The typical microstructure of $0 \mu \mathrm{m} @ \mathrm{E}-\mathrm{SiO}_{2 \mathrm{f}} / \mathrm{SiO}_{2}-\mathrm{Nb}, 50 \mu \mathrm{m} @ \mathrm{E}-\mathrm{SiO}_{2 \mathrm{f}} / \mathrm{SiO}_{2}-\mathrm{Nb}, 75 \mu \mathrm{m} @ \mathrm{E}-\mathrm{SiO}_{2 \mathrm{f}} / \mathrm{SiO}_{2}-\mathrm{Nb}, 100 \mu \mathrm{m} @ \mathrm{E}-\mathrm{SiO}_{2 \mathrm{f}} /$ $\mathrm{SiO}_{2}-\mathrm{Nb}, 125 \mu \mathrm{m} @ \mathrm{E}-\mathrm{SiO}_{2 \mathrm{f}} / \mathrm{SiO}_{2}-\mathrm{Nb}$ and $150 \mu \mathrm{m} @ \mathrm{E}-\mathrm{SiO}_{2 \mathrm{f}} / \mathrm{SiO}_{2}-\mathrm{Nb}$ joints brazed by AgCuTi brazing alloy at $840^{\circ} \mathrm{C}$ for $10 \mathrm{~min}$ are shown in Fig. 11. It is obvious that the interfacial microstructure changed with the depth of brazing alloy infiltrating into $\mathrm{SiO}_{2 \mathrm{f}} / \mathrm{SiO}_{2}$ increasing. As for $0 \mu \mathrm{m} @ \mathrm{E}-\mathrm{SiO}_{2 \mathrm{f}} / \mathrm{SiO}_{2}-\mathrm{Nb}$ joint, continuous cracks can be observed in $\mathrm{SiO}_{2 \mathrm{f}} / \mathrm{SiO}_{2}$ side near the brazing interface (see Fig. 11a). It may be because the poor wettability of $\mathrm{SiO}_{2 f} / \mathrm{SiO}_{2}$ and the high residual stress induced by the CTE mismatch between $\mathrm{SiO}_{2 \mathrm{f}} / \mathrm{SiO}_{2}$ and Nb. So, the shear stress of the $0 \mu \mathrm{m} @ \mathrm{E}-\mathrm{SiO}_{2 \mathrm{f}} / \mathrm{SiO}_{2}-\mathrm{Nb}$ joint was only $5 \mathrm{MPa}$ (see Fig. 12). When $\mathrm{SiO}_{2 \mathrm{f}} / \mathrm{SiO}_{2}$ after etching treatment, the brazed joint exhibited a $3 \mathrm{D} \mathrm{SiO}_{2 \mathrm{f}} / \mathrm{SiO}_{2}$-metal gradient transition zone and the width of the zone increased with the etching depth increasing (see Fig. 11b-d). Further, the brazing alloy was able to fill up the space between the quartz fibers and formed a sound metallurgical bonding with them, due to the great wettability of $\mathrm{E}-\mathrm{SiO}_{2 \mathrm{f}} / \mathrm{SiO}_{2}$. Furthermore, the "3D-pinning structure" can effectively reduce the residual stress in the joint, which decrease the continuous cracks and strengthen the joint. Thus, the shear strength of the joints increases from $5 \mathrm{MPa}$ to $61.9 \mathrm{MPa}$ with the etching depth increasing from 0 to $100 \mu \mathrm{m}$. However, the shear strength of the joints decreased with the etching depth increasing over $100 \mu \mathrm{m}$, because of the residual stress in the joints was increasing by the $\tau_{x y}$ of the "3D-pinning structure", according to the FEA results (see Fig. 12). 

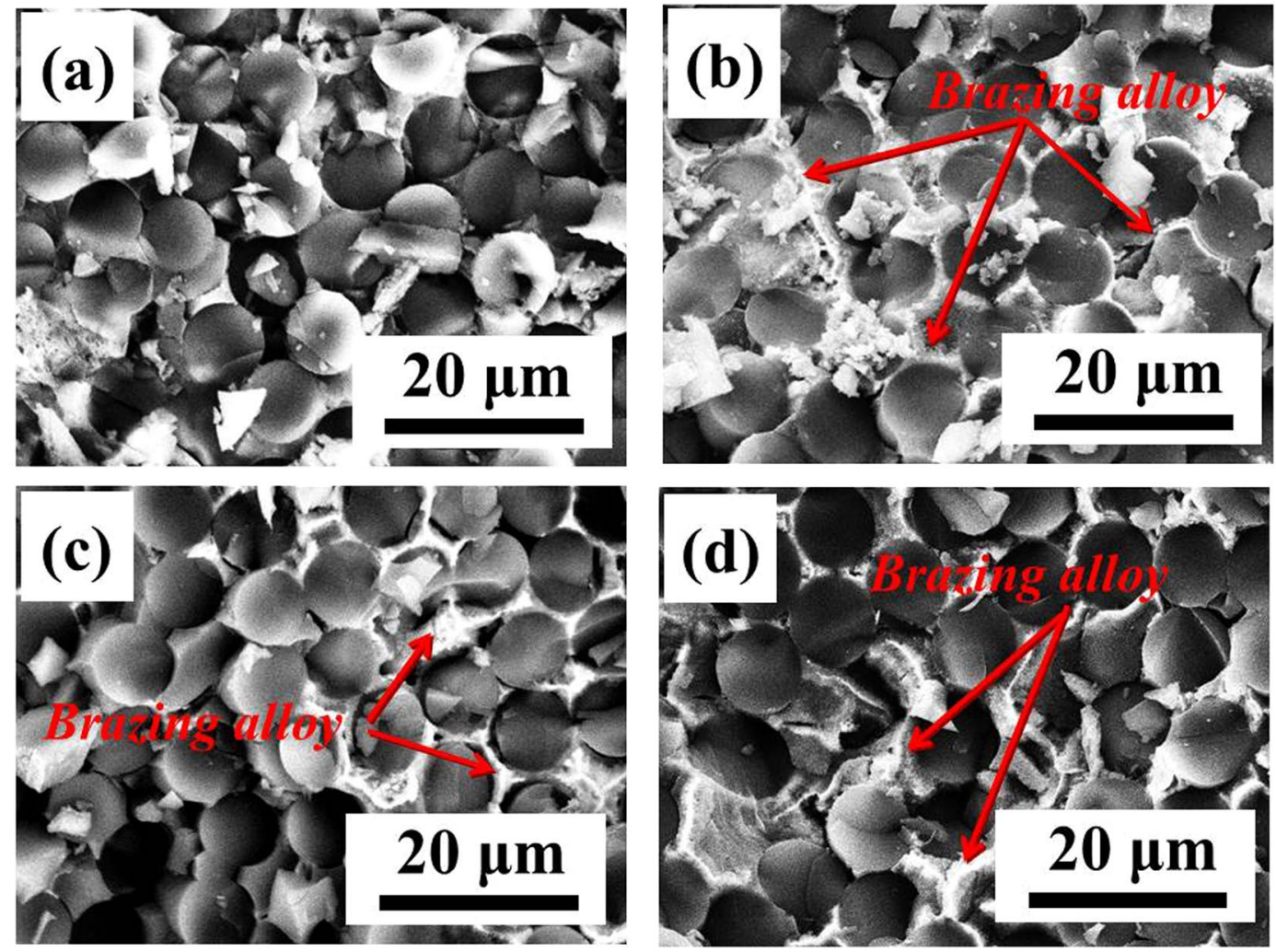

Figure 13. SEM images of the fracture surface in (a) $0 \mu \mathrm{m} @ \mathrm{E}-\mathrm{SiO}_{2 \mathrm{f}} / \mathrm{SiO}_{2}-\mathrm{Nb}$, , b) $50 \mu \mathrm{m} @ \mathrm{E}-\mathrm{SiO}_{2 \mathrm{f}} / \mathrm{SiO}{ }_{2}-\mathrm{Nb},(\mathbf{c})$ $100 \mu \mathrm{m} @ \mathrm{E}-\mathrm{SiO}_{2 f} / \mathrm{SiO}_{2}-\mathrm{Nb}$ and (d) $150 \mu \mathrm{m} @ \mathrm{E}-\mathrm{SiO}_{2 f} / \mathrm{SiO}_{2}-\mathrm{Nb}$ joint.
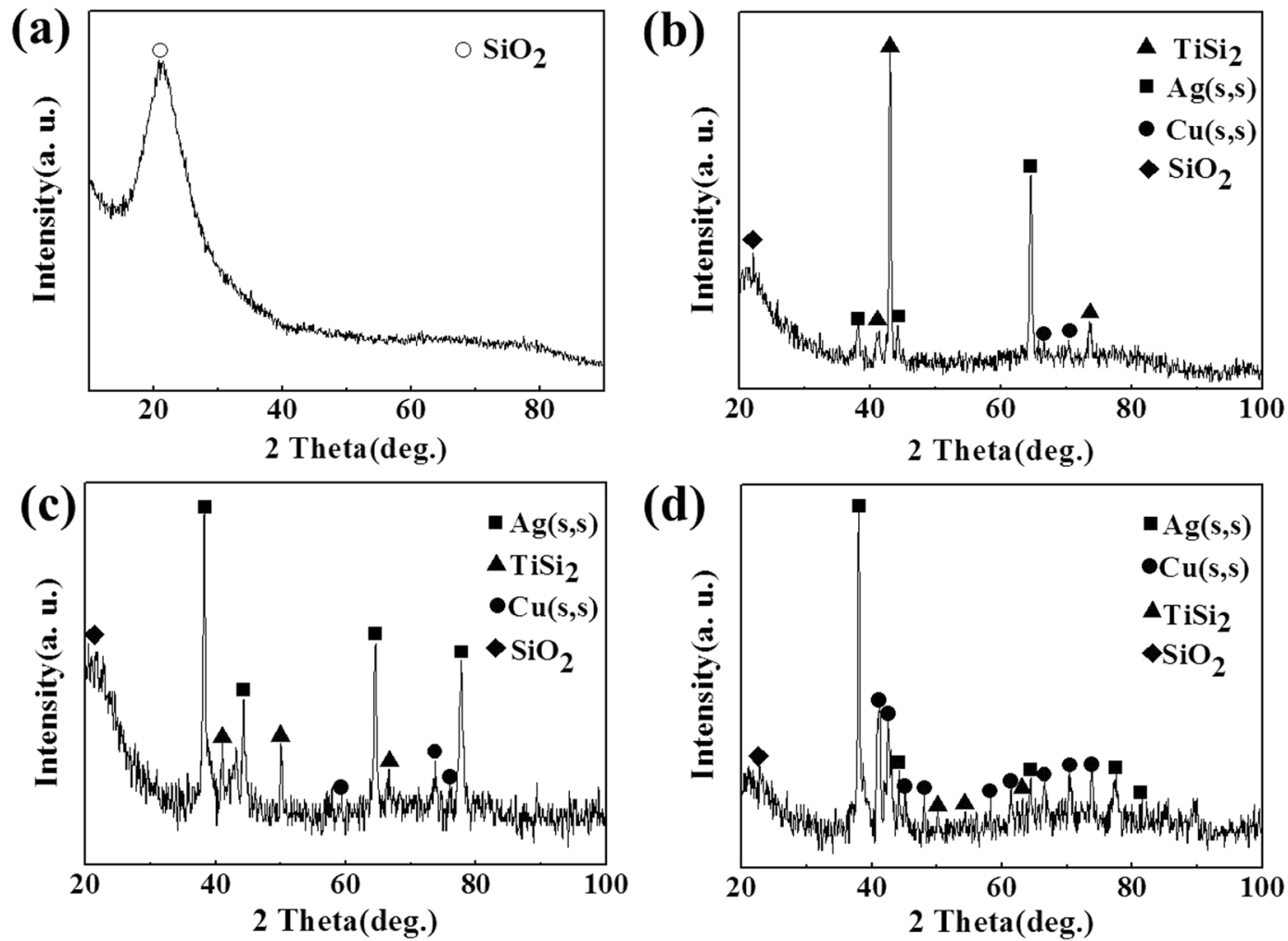

Figure 14. XRD result patterns of fracture surface of (a) $0 \mu \mathrm{m} @ \mathrm{E}-\mathrm{SiO}_{2 f} / \mathrm{SiO}_{2}-\mathrm{Nb},(\mathbf{b}) 50 \mu \mathrm{m} @ \mathrm{E}-\mathrm{SiO}_{2 f} / \mathrm{SiO}_{2}-\mathrm{Nb}$, (c) $100 \mu \mathrm{m} @ \mathrm{E}-\mathrm{SiO}_{2 \mathrm{f}} / \mathrm{SiO}_{2}-\mathrm{Nb}$, and (d) $150 \mu \mathrm{m} @ \mathrm{E}-\mathrm{SiO}_{2 \mathrm{f}} / \mathrm{SiO}_{2}-\mathrm{Nb}$ joint. 
In order to further study the effect of the transition zone on the obtained joints, the fracture analysis was conducted. Figure 13 shows the fracture surface of joints after shear tests. It can be seen that only remained broken quartz fibers were left in the fracture of $\mathrm{SiO}_{2 f} / \mathrm{SiO}_{2}-\mathrm{Nb}$ joint, as shows in Fig. 13a, which may be due to the cracks at $\mathrm{SiO}_{2 \mathrm{f}} / \mathrm{SiO}_{2}$ side caused by the high CTE mismatch. By contrast, almost the same type of fracture morphology for the $\mathrm{E}-\mathrm{SiO}_{2 f} / \mathrm{SiO}_{2}-\mathrm{Nb}$ joints can be observed in Fig. 13b-d. The brazing alloy infiltrated into $\mathrm{E}-\mathrm{SiO}_{2 \mathrm{f}} / \mathrm{SiO} \mathrm{O}_{2} \mathrm{can}$ be observed in fractures. In addition, XRD was used to confirm the reaction products at the fracture surface. As shown in Fig. 14a, it can be seen that the fracture of $\mathrm{SiO}_{2 \mathrm{f}} / \mathrm{SiO}_{2}-\mathrm{Nb}$ joint was only composed of amorphous silicon dioxide. Correspondingly, amorphous silicon dioxide, $\mathrm{TiSi}_{2}, \mathrm{Ag}(\mathrm{s}, \mathrm{s})$ and $\mathrm{Cu}(\mathrm{s}, \mathrm{s})$ were the reaction phases on the $\mathrm{SiO}_{2 \mathrm{f}} / \mathrm{SiO}_{2}$ composite fracture side for the fractures of $50 \mu \mathrm{m} @ \mathrm{E}-\mathrm{SiO}_{2 \mathrm{f}} / \mathrm{SiO}_{2}-\mathrm{Nb}, 100 \mu \mathrm{m} @ \mathrm{E}-\mathrm{SiO}_{2 \mathrm{f}} / \mathrm{SiO}_{2}-\mathrm{Nb}$ and $150 \mu \mathrm{m} @ \mathrm{E}-\mathrm{SiO}_{2 \mathrm{f}} / \mathrm{SiO}_{2}-\mathrm{Nb}$ joints (see Fig. 14b-d). According to the XRD patterns, it can be inferred that as for $\mathrm{SiO}_{2 f} / \mathrm{SiO}_{2}-\mathrm{Nb}$ joint, fracture occurred along the brazing interface on the $\mathrm{SiO}_{2 f} / \mathrm{SiO}_{2}$ composite side. It may be due to the residual stress constraining around the $\mathrm{SiO}_{2 \mathrm{f}} / \mathrm{SiO}_{2}-\mathrm{AgCuTi}$ interface. Moreover, for $50 \mu \mathrm{m} @ \mathrm{E}-\mathrm{SiO}_{2 \mathrm{f}} /$ $\mathrm{SiO}_{2}-\mathrm{Nb}, 100 \mu \mathrm{m} @ \mathrm{E}-\mathrm{SiO}_{2 \mathrm{f}} / \mathrm{SiO}_{2}-\mathrm{Nb}$ and $150 \mu \mathrm{m} @ \mathrm{E}-\mathrm{SiO}_{2 \mathrm{f}} / \mathrm{SiO}_{2}-\mathrm{Nb}$ joints, fracture occurred in the $3 \mathrm{D} \mathrm{SiO}_{2 \mathrm{f}} /$ $\mathrm{SiO}_{2}$-metal gradient transition zone. Although the morphologies of the three kinds of fractures were almost the same, the mechanical properties of the joints were different, which may be owing to the residual stress concentrated in that zone.

Based on the above results, it is suggested that the FEA results can serve as a guide for the brazing test and a theoretical basis for the distribution of residual stress in the brazed joints. In addition, the results show clearly that the etching treatment plays a key role in two major aspects on active brazing $\mathrm{SiO}_{2 f} / \mathrm{SiO}_{2}$ and $\mathrm{Nb}$. On the one hand, it can effectively improve the wettability of $\mathrm{SiO}_{2 \mathrm{f}} / \mathrm{SiO}_{2}$, which is a precondition of successfully brazing $\mathrm{SiO}_{2 \mathrm{f}} /$ $\mathrm{SiO}_{2}$ and $\mathrm{Nb}$. On the other hand, it can induce the brazing alloy infiltrating into $\mathrm{E}-\mathrm{SiO}_{2 \mathrm{f}} / \mathrm{SiO}_{2}$, which increases the bonded area, reduces the residual stress and enhances the mechanical properties. Therefore, regulating the surface structure is an easy and effective method to reduce the residual stress, which can strength the joints. As well the FEA and the brazing test results both reveal that the properties of $100 \mu \mathrm{m} @ \mathrm{SiO}_{2 \mathrm{f}} / \mathrm{SiO}_{2}-\mathrm{Nb}$ joint is the best among the obtained brazed joints with different surface structures.

\section{Conclusions}

In this paper, the optimized depth of brazing alloy infiltrating into $\mathrm{SiO}_{2 f} / \mathrm{SiO}_{2}$ was achieved by combining FEA with experiments. After etching treatment, the fused silica with poor wettability has been consumed while the quartz fibers with good wettability were left, thus the wettability of $\mathrm{E}-\mathrm{SiO}_{2 \mathrm{f}} / \mathrm{SiO}_{2}$ was improved. The good wettability of $\mathrm{SiO}_{2 \mathrm{f}} / \mathrm{SiO}_{2}$ played an important role in obtaining a high-quality joint. Moreover, "3D-pinning structure" formed in $\mathrm{E}_{-} \mathrm{SiO}_{2 \mathrm{f}} / \mathrm{SiO}_{2}-\mathrm{Nb}$ joints, which can reduce the residual stress in the joint by form the sound gradient transition of CTE. However, the residual stress rather reduced with the etching depth increasing over appropriate size, due to the $\tau_{x y}$ introduced by the "3D-pinning structure". A relationship between the residual stress, the surface structure and the joint property in the brazed joints was demonstrated. As well the FEA and the brazing test results both realized the high-quality joint of $\mathrm{E}-\mathrm{SiO}_{2 \mathrm{f}} / \mathrm{SiO}_{2}-\mathrm{Nb}$ joint and the shear strength of the joint reached 61.9 $\mathrm{MPa}$, which was approximately 12 times than that of $\mathrm{SiO}_{2 \mathrm{f}} / \mathrm{SiO}_{2}-\mathrm{Nb}$ joint.

\section{References}

1. Liu, Y. et al. Comparison of $3 \mathrm{D}$ four-directional and five-directional braided $\mathrm{SiO}_{2 \mathrm{f}} / \mathrm{SiO}_{2}$ composites with respect to mechanical properties and fracture behavior. Mater. Sci. Eng. A 558, 170-174 (2012).

2. Li, B., Lin, L., Zhu, J., Liu, Y. \& Chen, Z. Mechanical properties and microstructure of 3D 6-Directional braided $\mathrm{SiO}_{2 \mathrm{f}} / \mathrm{SiO}_{2}$ composites by silicasol-infiltration-sintering method. Asian J. Chem. 25, 23-26 (2013).

3. Tian, X. Y., Feng, J. C., Shi, J. M., Li, H. W. \& Zhang, L. X. Brazing of $\mathrm{ZrB}_{2}-\mathrm{SiC}-\mathrm{C}$ ceramic and GH99 superalloy to form reticular seam with low residual stress. Ceram. Int. 41, 145-153 (2015).

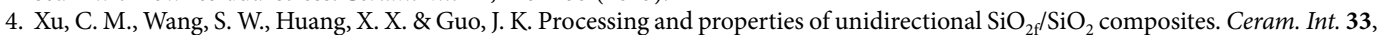
669-673 (2007).

5. Ali, M., Knowles, K. M., Mallinson, P. M. \& Fernie, J. A. Microstructural evolution and characterization of interfacial phases in $\mathrm{Al}_{2} \mathrm{O}_{3} / \mathrm{Ag}-\mathrm{Cu}-\mathrm{Ti} / \mathrm{Al}_{2} \mathrm{O}_{3}$ braze joints. Acta Mater. 96, 143-158 (2015).

6. Wang, D., Cao, J., Li, W. J., Dai, X. Y. \& Feng, J. C. Zr hydrogenation by cathodic charging and its application in TC4 alloy diffusion bonding. Int. J. Hydrogen Energy, doi:10.1016/j.ijhydene.2016.11.170.

7. Hanson, W. B., Ironside, K. I. \& Fernie, J. A. Active metal brazing of zirconia. Acta Mater. 48, 4673-4676 (2000).

8. Philips, N. R., He, M. Y. \& Evans, A. G. A wedge fracture toughness test for intermediate toughness materials: Application to brazed joints. Acta Mater. 56, 4593-4600 (2008).

9. Kang, K. J. A wire-woven cellular metal of ultrahigh strength. Acta Mater. 57, 1865-1874 (2009).

10. Si, X. Q., Cao, J., Song, X. G., Qu, Y. \& Feng, J. C. Reactive air brazing of YSZ ceramic with novel $\mathrm{Al}_{2} \mathrm{O}_{3}$ nanoparticles reinforced Ag$\mathrm{CuO}-\mathrm{Al}_{2} \mathrm{O}_{3}$ composite filler: Microstructure and joint properties. Mater. Des. 114, 176-184 (2017).

11. Blugan, G., Rusch, J. J. \& Kuebler, J. Properties and fractography of $\mathrm{Si}_{3} \mathrm{~N}_{4} / \mathrm{TiN}$ ceramic joined to steel with active single layer and double layer braze filler alloys. Acta Mater. 52, 4579-4588 (2004).

12. Chen, H. et al. Reactive air brazing for sealing mixed ionic electronic conducting hollow fiber membranes. Acta Mater. 88, 74-82 (2015).

13. Yang, Z. W. et al. Interlayer design to control interfacial microstructure and improve mechanical properties of active brazed Invar/ $\mathrm{SiO}_{2}$-BN joint. Mater. Sci. Eng. A 575, 199-205 (2013).

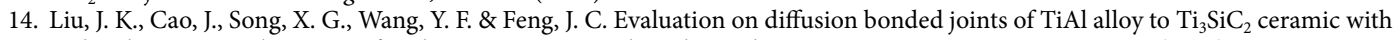
and without Ni interlayer: Interfacial microstructure and mechanical properties. Mater. Design 57, 592-597 (2014).

15. Lan, L. et al. Interfacial microstructure and mechanical characterization of silicon nitride/nickel-base superalloy joints by partial transient liquid phase bonding. Ceram. Int. 42, 1633-1639 (2016).

16. Laik, A., Mishra, P., Bhanumurthy, K., Kale, G. B. \& Kashyap, B. P. Microstructural evolution during reactive brazing of alumina to Inconel 600 using Ag-based alloy. Acta Mater. 61, 126-138 (2013).

17. Kozlova, O. et al. Brazing copper to alumina using reactive CuAgTi alloys. Acta Mater. 58, 1252-1260 (2010).

18. Kooistra, G. W., Deshpande, V. S. \& Wadley, H. N. G. Compressive behavior of age hardenable tetrahedral lattice truss structures made from aluminium. Acta Mater. 52, 4229-4237 (2004).

19. Turriff, D. M., Corbin, S. F. \& Kozdras, M. Diffusional solidification phenomena in clad aluminum automotive braze sheet. Acta Mater. 58, 1332-1341 (2010). 
20. Shiue, R. K., Wu, S. K. \& Chen, S. Y. Infrared brazing of TiAl intermetallic using Bag-8 braze alloy. Acta Mater. 51, 1991-2004 (2003).

21. Ali, M., Knowles, K. M., Mallinson, P. M. \& Fernie, J. A. Interfacial reactions between sapphire and Ag-Cu-Ti-brazed active braze alloys. Acta Mater. 103, 859-869 (2016).

22. Arroyave, R. \& Eagar, T. W. Metal substrate effects on the thermochemistry of active brazing interfaces. Acta Mater. 51, 4871-4880 (2003).

23. Zhao, L., Zhang, L. X., Tian, X. Y., He, P. \& Feng, J. C. Interfacial microstructure and mechanical properties of joining electroless nickel plated quartz fibers reinforced silica composite to Invar. Mater. Design 32, 382-387 (2011).

24. Zhao, L., Feng, J. C., Tian, X. Y., Zhang, L. X. \& He, P. Brazing of micrograin-filled quartz fiber reinforced silica composites and Invar using Ag-21Cu-4.5 Ti alloy. Chin. Sci. Bull. 56, 2869-2873 (2011).

25. Sun, Z. et al. Brazing of $\mathrm{SiO}_{2 f} / \mathrm{SiO}_{2}$ composite modified with few-layer graphene and Invar using AgCuTi alloy. Mater. Design 88, $51-57$ (2015).

26. Zhang, Y. et al. Vacuum brazing of alumina to stainless steel using femtosecond laser patterned periodic surface structure. Mater. Sci. Eng. A 662, 178-184 (2016).

27. Wang, H. Q., Cao, J. \& Feng, J. C. Brazing mechanism and infiltration strengthening of CC composites to TiAl alloys joint. Scripta Mater. 63, 859-862 (2010).

28. Shen, Y. X., Li, Z. L., Hao, C. Y. \& Zhang, J. S. A novel approach to brazing C/C composite to Ni-based superalloy using alumina interlayer. J. Eur. Ceram. Soc. 32, 1769-1774 (2012)

29. Liu, Y., Zhu, J. X., Chen, Z. F. \& Jiang, Y. Mechanical behavior of 2.5D (shallow straight-joint) and 3D four-directional braided $\mathrm{SiO}_{2 \mathrm{f}} /$ $\mathrm{SiO}_{2}$. composites, Ceram. Inter. 38, 4245-4251 (2012).

30. Galli, M., Botsis, J., Janczak-Rusch, J., Maier, G. \& Welzel, U. Characterization of the residual stresses and strength of ceramic-metal braze joints. J. Eng. Mater. Technol. 131, 021004-3 (2009).

31. Deng, D. FEM prediction of welding residual stress and distortion in carton steel considering phase transformation effects. Mater. Des. 30, 359-366 (2009).

32. Rosa, R. et al. Microwave assisted combustion synthesis in the system Ti-Si-C for the joining of SiC: Experimental and numerical simulation results. J. Eur. Ceram. Soc. 33, 1707-1719 (2013).

33. Webb, E. B. \& Hoyt, J. J. Molecular dynamics study of liquid metal infiltration during brazing. Acta Mater. 56, 1802-1812 (2008).

34. Rosa, R., Veronesi, P. \& Han, S. et al. Microwave assisted combustion synthesis in the system Ti-Si-C for the joining of SiC: Experimental and numerical simulation results. J. Eur. Ceram. Soc. 33, 1707-1719 (2013).

35. Wang, Y., Yang, Z. W. \& Zhang, L. X. et al. Microstructure and mechanical properties of $\mathrm{SiO}_{2}-\mathrm{BN}$ ceramic and Invar alloy joints brazed with Ag-Cu- $\mathrm{Ti}+\mathrm{TiH}_{2}+\mathrm{BN}$ composite filler. J. Materiomics 2, 66-74 (2016).

36. Zhang, Y., Zou, G. \& Liu, L. et al. Vacuum brazing of alumina to stainless steel using femtosecond laser patterned periodic surface structure. Mater. Sci. Eng., A 662, 178-184 (2016).

37. Wang, T. P., Ivas, T. \& Lee, W. et al. Relief of the residual stresses in Si3N4/Invar joints by multi-layered braze structure - Experiments and simulation, Ceram. Inter 42, 7080-7087 (2016).

38. Ma, Q., Qi, J. L. \& Feng, J. C. et al. Regulating the surface structure of $\mathrm{SiO}_{2 f} / \mathrm{SiO}_{2}$ composite for assisting in brazing with Nb. Mater. Lett. 182, 159-162 (2016).

39. Tanaka, C. B., Harisha, H., Baldassarri, M. et al. Experimental and finite element study of residual thermal stresses in veneered Y-TZP structures, Ceram. Inter, doi:10.1016/j.ceramint.2016.03.018 (2016).

40. Nayebpashaee, N., Seyedein, S. H. \& Aboutalebi, M. R. et al. Finite element simulation of residual stress and failure mechanism in plasma sprayed thermal barrier coatings using actual microstructure as the representative volume. Surf. Coat. Technol. 291, 103-114 (2016).

41. Wang, T. P., Ivas, T., Lee, W., Leinenbach, C. \& Zhang, J. Relief of the residual stresses in $\mathrm{Si}_{3} \mathrm{~N}_{4} /$ Invar joints by multi-layered braze structure - Experiments and simulation, Ceram. Inter. 42, 7080-7087 (2016).

42. Laik, A., Mishra, P., Bhanumurthy, K., Kale, G. B. \& Kashyap, B. P. Stability of microstructure and its evolution during solid-state annealing of $\mathrm{Al}_{2} \mathrm{O}_{3}$-Inconel 600 brazed couples. Acta Mater. 59, 5092-5102 (2011).

43. Voytovych, R., Robaut, F. \& Eustathopoulos, N. The relation between wetting and interfacial chemistry in the CuAgTi/alumina system. Acta Mater. 54, 2205-2214 (2006).

\section{Acknowledgements}

The authors acknowledge Yue Zhou for assistance with microstructure of the joints, Jian Zhang for assistance with mechanical properties of the joints, and Heng Ze Xian for assistance with XRD test on the fractures. This project is supported by National Natural Science Foundation of China (Grant No. 51575135 and U1537206).

\section{Author Contributions}

Jun Lei Qi and Qiang Ma conceived and designed the experiments. Jin Ba performed the experiments. Jing Huang Lin and Ze Yu Wang analyzed the data. Lai Shan Yang prepared Figures 4-5. Qiang Ma performed the data analyses and wrote the main manuscript. Ju Lei Qi, Ji Cai Feng and Zhuo Ran Li contributed reagents/materials/ analysis tools.

\section{Additional Information}

Supplementary information accompanies this paper at doi:10.1038/s41598-017-04531-w

Competing Interests: The authors declare that they have no competing interests.

Publisher's note: Springer Nature remains neutral with regard to jurisdictional claims in published maps and institutional affiliations.

Open Access This article is licensed under a Creative Commons Attribution 4.0 International License, which permits use, sharing, adaptation, distribution and reproduction in any medium or format, as long as you give appropriate credit to the original author(s) and the source, provide a link to the Creative Commons license, and indicate if changes were made. The images or other third party material in this article are included in the article's Creative Commons license, unless indicated otherwise in a credit line to the material. If material is not included in the article's Creative Commons license and your intended use is not permitted by statutory regulation or exceeds the permitted use, you will need to obtain permission directly from the copyright holder. To view a copy of this license, visit http://creativecommons.org/licenses/by/4.0/.

(c) The Author(s) 2017 